\title{
Supraoptimal nitrogen sidedressing on morpho-agronomic traits of maize
}

\author{
Cobertura nitrogenada supraótima sobre características morfo-agronômicas do milho
}

\author{
Mariana Mendes Fagherazzi, Clovis Arruda Souza*, Ricardo Trezzi Casa e Cileide Maria Medeiros \\ Coelho
}

Recebido em 11/09/2015 / Aceito em 30/11/2015.

\begin{abstract}
Nitrogen is the element that has the most influence on grain yield in maize plantations; however, the excess of this nutrient increases the likelihood of lodging. The occurrence of lodging can be prevented by applying a plant growth regulator. In this respect, an experiment was carried out to evaluate the effects of nitrogen sidedressing above the ideal level, associated with the use of trinexapac-ethyl in maize cv. P30R50H. The experiment was conducted under field conditions during the season 2013/2014, in Lages - SC. The experimental design was a randomized block design with four replications, and the treatments consisted of four nitrogen rates and a rate of trinexapacethyl applied at all nitrogen rates. Nitrogen rates were equivalent to $1.0,1.35,1.70$ and 2.0 times the required rate to reach the yield of $12 \mathrm{t} \mathrm{ha}^{-1}$. The $\mathrm{N}$ sidedressing rates were equally divided and applied on plants at phenological stages V4, V7 and V9. The trinexapac-ethyl was applied when the plants reached V10 (ten fully developed leaves) at a concentration of $300 \mathrm{~g}$ a.i. ha ${ }^{-1}$. Only the variable length of the leaf opposite the ear increased with increasing the ideal level of nitrogen sidedressing. Lodging, plant height, leaf chlorophyll, grain yield and nitrogen content in the grains were not affected by $\mathrm{N}$ sidedressing above the ideal level, associated with the use of trinexapacethyl.
\end{abstract}

KEYWORDS: Zea mays, fertilization, lodging, agricultural yield.

\section{RESUMO}

O nitrogênio é o elemento que exerce maior influência sobre o rendimento de grãos na cultura do milho, no entanto, o excesso desse nutriente aumenta a probabilidade de ocorrência do acamamento, mas a ocorrência de acamamento pode ser evitada com a aplicação de regulador de crescimento. Neste sentido, realizou-se um experimento para avaliar os efeitos da adubação nitrogenada em cobertura supraótima, associado ao uso de etil-trinexapac em milho cv. P30R50H. O experimento foi conduzido a campo, durante a safra agrícola 2013/2014, em Lages SC. O delineamento experimental foi de blocos ao acaso, com quatro repetições, sendo os tratamentos constituídos por quatro doses de nitrogênio, e uma dose de etil-trinexapac aplicado em todos os níveis de nitrogênio. As doses de nitrogênio equivalentes a 1,0, $1,35,1,70$ e 2,0 vezes a dose necessária para atingir produtividade de $12 \mathrm{t} \mathrm{ha}^{-1}$. As doses de $\mathrm{N}$ em cobertura foram parceladas igualmente e aplicadas sobre plantas nos estádios fenológicos de V4, V7 e V9. O etiltrinexapac foi aplicado quando as plantas atingiram V10 (dez folhas completamente desenvolvidas), na concentração de 300 g i.a. ha ${ }^{-1}$. Apenas a variável, comprimento da folha oposta a espiga respondeu positivamente ao aumento da adubação nitrogenada supraótima aplicada em cobertura. As características de acamamento, estatura de plantas, clorofila na folha, rendimento de grãos e nitrogênio nos grãos não foram afetadas pela adubação de $\mathrm{N}$ supraótima associada ao uso de etil-trinexapac.

PALAVRAS-CHAVE: Zea mays, adubação, acamamento, produtividade agrícola.

Nitrogen is one of the nutrients required in higher amounts by maize plantations, and it plays an important role in increasing grain yield (LOURENTE et al. 2007, CIAMPITTI \& VYN 2014). The absorption of nitrogen from mineral fertilizers by

Universidade do Estado de Santa Catarina, Lages, SC, Brasil.

*Autor para correspondência <souza_clovis@yahoo.com.br>. 
maize is reduced with increased application rate, because the supply exceeds the needs of the crop and there are possible losses of nitrogen, mainly through leaching, volatilization and denitrification (SILVA et al. 2006). Rates and timing of nitrogen application are alternatives to increase the efficiency of fertilizers and nitrogen fertilization in maize crops in order to mitigate any losses of this nutrient.

The use of plant growth regulators is a management strategy farmers can adopt to avoid excess growth and vigor of maize plants under high population density, associated with high rates of nitrogen side-dressing, when grain yield is aimed at higher levels, for example, above $18 \mathrm{t} \mathrm{ha}^{-1}$ grains (SCHMITT et al. 2012). Such a combination of nutritional improvement associated with increased plant density can result in susceptibility to plant lodging; such susceptibility can be possibly minimized by the use of growth retardants. Trinexapac-ethyl is one of the plant growth regulators which inhibit gibberellin biosynthesis, responsible for cell division and elongation (RADEMACHER 2000). Although trinexapac-ethyl is used for management of plant height for wheat, barley and also garden grass, there are few reports on the use of trinexapac-ethyl in maize plants (ZAGONEL \& FERREIRA 2013). Given the above-mentioned context, the objective of this study was to evaluate the effect of nitrogen sidedressing above the ideal level, combined with the use of trinexapac-ethyl, on morphological and productive traits in maize plants.

The work was conducted in field conditions, at Lages - SC, Brazil. Meteorological data (maximum, average, and minimum temperatures and rainfall) were collected from the Environmental Resources and Hydrometeorology Information Center of Santa Catarina State University, in the municipality of Lages (Figure 1).

Maize sowing was mechanically held on October, 23 of 2013 year using the simple hybrid P30R50H with a density of 9 plants $\mathrm{m}^{-2}$. Each experimental plot consisted of four lines of $5 \mathrm{~m}$ length, spaced at $0.60 \mathrm{~m}$ among rows; the evaluation only took into account the useful area composed of the two inner rows. For soil lines fertilization, $503 \mathrm{~kg} \mathrm{ha}^{-1}$ of the NPK formulation (5-20-10) applied to obtain the yield threshold of $12 \mathrm{t} \mathrm{ha}^{-1}$ was used (CQFS-RS/SC 2004).

The experimental design was a randomized block design with four replications. The tested nitrogen rates were equivalent to $1.0,1.35,1.70$ and 2.0 times the rate required to achieve the yield of $12 \mathrm{t} \mathrm{ha}^{-1}$. Quantitatively, these rates of nitrogen sidedressing are equivalent to $190,216,323$ and 380 $\mathrm{kg} \mathrm{ha}^{-1} \mathrm{~N}$. The nitrogen split sidedressings were made at the three growth stages of plants, V4, V7 and V9

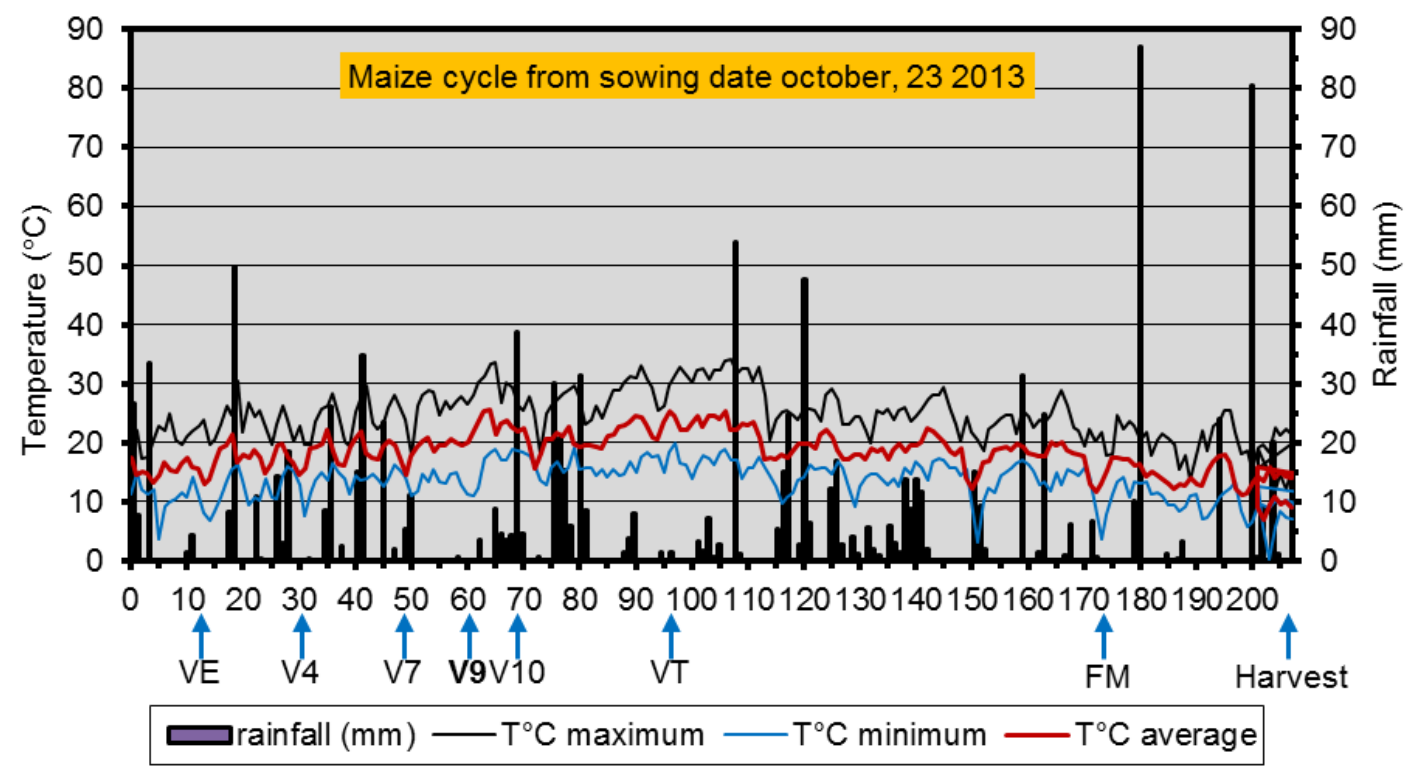

Figure 1 - Maximum, minimum and average air temperatures and rainfall levels in the experimental period between the sowing and harvest and evolution of plant phenology. VE: Emergence; at V4, V7 and V9, respectively, the plants received nitrogen sidedressing; at V10, application of trinexapac-ethyl and VT: bolting, PM: physiological maturity and harvest. Lages- SC, 2013/2014 growing season. 
according to the Ritchie scale (RITCHIE et al. 1993). This splitting aimed minimizing the potential losses of N. A plant growth regulator named trinexapac-ethyl (MODDUS $\AA$ ) was sprayed when the plants reached the growth stage V10 (ten fully expanded leaves) at a concentration of $300 \mathrm{~g}$ a.i. $\mathrm{ha}^{-1}$, corresponding to $1.2 \mathrm{~L} \mathrm{ha}^{-1}$ of the commercial product. The trinexapacethyl was sprayed at all levels of nitrogen treatments.

At flowering, plant height and ear insertion height were determined in ten plants of the two center rows of each plot, and stem diameter was measured at $0.20 \mathrm{~m}$ above the ground, with the aid of a digital caliper. Leaf length and leaf width (above and opposite the ear) were assessed with a ruler. The leaf area of the main stem was calculated by the expression. $\mathrm{LA}=\mathrm{L}$ x W x 0.75, as described by SANGOI et al. (2011).

The lodging index was visually estimated in percentage terms, based on the angle between the vertical position of the stalk on the ground and the area of lodged plants, according to the Belgian lodging index (MOES \& STOBBE 1991), adapted for maize, according to the equation $\mathrm{LI} \%=\mathrm{S} \times \mathrm{I} \times 2$, where $\mathrm{S}=$ lodging surface (obtained from the area equivalent to the number of fallen plants compared with the area of the total number of plants per plot) ranging from 0 to 10 where $0=$ no lodging and $10=$ totally lodged; and $\mathrm{I}=$ lodging intensity, $1=$ plants vertically and $5=$ plants horizontally; and $2=$ correction coefficient for percentage.
Chlorophyll was measured when the plants bolted, by use of the clorofiLOG (Falker $($ ) chlorophyll meter. Readings were made at the central blade of the opposite ear leaf on ten plants per treatment between 9:00 and 10:00 am. At harvest time, the number of ears per plant was determined (obtained from the total number of ears counted in the total number of plants of each useful area per plot), and the number of grains per ear was determined in ten ears per plot. The thousand grain weight $(\mathrm{g})$ was estimated by counting four sub-samples obtained from 1000 grains of each plot. Grain yield, expressed in $\mathrm{kg} \mathrm{ha}^{-1}$, was estimated from the grain yield of each plot useful area transformed to one hectare after correction of values and standardization at $13 \%$ of moisture content of these grains.

Nitrogen and crude protein (CP) levels were determined by the Kjeldahl method; then, the total nitrogen value $(\mathrm{N})$ was obtained indirectly after digestion of the grain sample in sulfuric acid, followed by distillation of the $\mathrm{N}$ present and titration to transform the $\mathrm{N}$ into ammonia salt (CAMPOS et al. 2004).

The data was submitted for analysis of variance using the F-test at 5\% level of probability, and to fit regression for the effect nitrogen rate when there was statistical significance.

In the findings, only the variable length of leaf opposite the ear (Figure 2) differed between

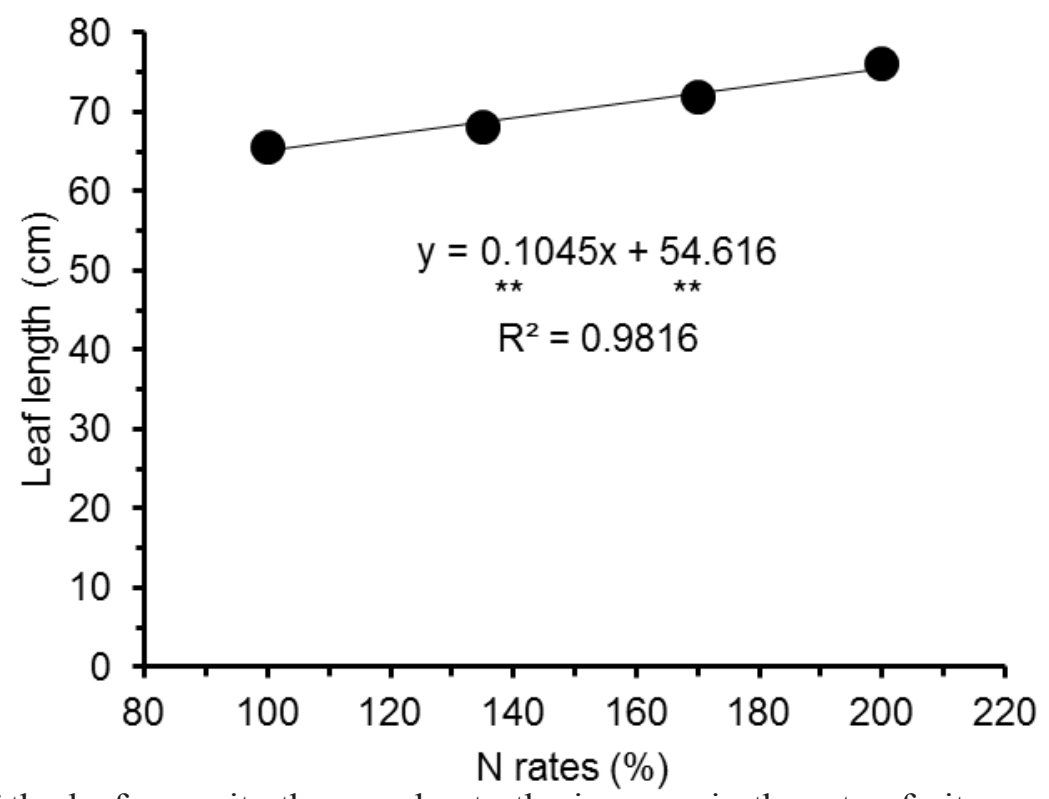

Figure 2 - Length of the leaf opposite the ear, due to the increase in the rate of nitrogen sidedressing, in the maize cultivar P30R50H. (100\%, 135\%, 170\% and 200\% represent 1.0, 1.35, 1.70 and 2.0 times the amount of nitrogen recommended in sidedressing for $12 \mathrm{t} \mathrm{ha}^{-1}$ grain yield). Lages-SC, 2014. 
treatments, while there were no differences for the other variables (Table 1 and 2). Figure 2 shows that the increased levels of nitrogen sidedressing resulted in a small improvement in the length of the leaf opposite the ear, on the order of $1.045 \mathrm{~mm}$ in response to each extra kilo of nitrogen applied per hectare. However, this did not alter the leaf area of this leaf, or its length, width and leaf area of other leaves (Table 1). There were different results for commercial maize hybrids Status TL and Maximus TLTG: changes occurred in the leaf morphological parameters of these hybrids due to an increase in the trinexapac-ethyl rate. There was a reduction in leaf length and an increase in leaf width; however, there were no changes in leaf area. The magnitude of effect depends on the rate of the product and on the genotype (ZAGONEL \& FERREIRA 2013). However, these changes occurred without any variation in the rates of nitrogen.

Stem diameter did not differ among the treatments (Table 1). A similar result was also found in other six maize cultivars and four nitrogen rates, i.e., there were no differences between treatments (FERNANDES et al. 2005). In another research study, there was no stem diameter difference by the use of nitrogen from different sources: Urea, Ammonium Sulphate and Entec at different rate combinations of this nutrient (MEIRA et al. 2009).

Nitrogen rates did not influence the levels of chlorophyll, nitrogen (\%) and crude protein (\%) in the leaves (Table 2). In an experiment with nitrogen rates $\left(0,70,140\right.$ and $\left.280 \mathrm{~kg} \mathrm{ha}^{-1} \mathrm{~N}\right)$ in maize, MOTA et al. (2015) concluded that the increasing application of nitrogen promotes increased chlorophyll content until the optimal level is reached; however, above the ideal level, there were no differences among rates for the chlorophyll variable. This may indicate that supraoptimal levels of nitrogen are not effective for the extra production of chlorophyll.

There was no effect of treatments for all grain yield components (Table 2). Grain yield obtained in all treatments did not reach the expected agricultural grain yield $\left(12 \mathrm{tha}^{-1}\right)$ that was aimed for by all fertilizers applied. Thus, even with high amounts of mineral nitrogen sidedressing, the average productivity was $7.5 \mathrm{t} \mathrm{ha}^{-1}$ (Table 2). Maize requires about $20 \mathrm{~kg} \mathrm{ha}^{-1}$ $\mathrm{N}$ for each ton of yield grain produced (CQFS-RS/ SC 2004; SOUZA et al. 2008; CIAMPITTI \& VYN 2014).

Nitrogen in the soil has a mass flow mechanism, which requires water in order to reach the plants root system, and thus be absorbed by them. Water stress occurred in January, 2014 coinciding with the growth stages of development of inflorescences, bolting and silking (Figure 1); it limited the productive potential of the crop in such a way that growth performance was only $7.5 \mathrm{t} \mathrm{ha}^{-1}$ grains, less than $12 \mathrm{t} \mathrm{ha}^{-1}$ of grains required. This finding can be explained due to increased asynchrony between male and female flowering, i.e., there is an increase in the interval between tassel emergence and the appearance of stigmas, within three to four days as a result of drought, leading to failure pollination and consequent development of infertile ears or ears with few grains (BERGAMASCHI et al. 2004)

Table 1 - Mean square for the traits: plant height (PH), ear insertion height (EIH), stem diameter (SD), length (LLA) and width of the leaf above the ear (WLA), length (LLO) and width of the leaf opposite the ear (WLO) observed on the maize cultivar P30R50H, under treatments (Treat) composed of nitrogen sidedressing combined with spraying trinexapac-ethyl. Lages-SC, 2013/2014 growing season.

\begin{tabular}{|c|c|c|c|c|c|c|c|c|}
\hline SV & DF & $\begin{array}{l}\mathrm{PH} \\
\text { (m) }\end{array}$ & $\begin{array}{l}\text { EIH } \\
(m)\end{array}$ & $\begin{array}{l}\text { SD } \\
(\mathrm{mm})\end{array}$ & $\begin{array}{l}\text { LLA } \\
(\mathrm{cm})\end{array}$ & $\begin{array}{l}\text { WLA } \\
(\mathrm{cm})\end{array}$ & $\begin{array}{l}\text { LLO } \\
(\mathrm{cm})\end{array}$ & $\begin{array}{l}\text { WLO } \\
(\mathrm{cm})\end{array}$ \\
\hline Treat & 3 & $0.02 \mathrm{~ns}$ & $0.01 \mathrm{~ns}$ & $0.46 \mathrm{~ns}$ & $65.83 \mathrm{~ns}$ & $0.25 \mathrm{~ns}$ & $84.73 *$ & $0.18 \mathrm{~ns}$ \\
\hline Block & 3 & $0.04 \mathrm{~ns}$ & $0.04 \mathrm{~ns}$ & $4.33 *$ & $10.23 \mathrm{~ns}$ & $0.27 \mathrm{~ns}$ & $10.41 \mathrm{~ns}$ & $0.32 \mathrm{~ns}$ \\
\hline Error & 9 & 0.02 & 0.01 & 0.55 & 30.67 & 0.42 & 14.94 & 0.36 \\
\hline Main & & 2.15 & 1.25 & 21.54 & 79.92 & 9.49 & 70.46 & 9.35 \\
\hline CV (\%) & & 6.93 & 9.68 & 3.43 & 6.93 & 6.83 & 5.49 & 6.43 \\
\hline
\end{tabular}

*statistically different by the F-test at $\mathrm{p}<0.05$; ns, does not differ statistically by the F-test ( $\mathrm{p}>0.05)$; $\mathrm{SV}=$ sources of variation; $\mathrm{DF}=$ degrees of freedom; $\mathrm{CV}=$ coefficient of variation. 
Table 2 - Mean square for the traits: crude protein (CP), nitrogen content (N\%), chlorophyll (CLP), number of grains per ear (NGE), thousand grain weight (TGW), ear per plant (EP), grain yield (Yield) and lodging index (LI) of the maize cultivar P30R50H, under treatments (Treat) composed of nitrogen sidedressing combined with spraying trinexapac-ethyl. Lages-SC, 2013/2014 growing season.

\begin{tabular}{|c|c|c|c|c|c|c|c|c|c|}
\hline SV & $\mathrm{DF}$ & $\begin{array}{l}\mathrm{CP} \\
(\%)\end{array}$ & $\begin{array}{l}\mathrm{N} \\
(\%)\end{array}$ & $\begin{array}{l}\text { CLP } \\
\text { (a.u.) }\end{array}$ & $\begin{array}{l}\text { NGE } \\
\text { (un.) }\end{array}$ & $\begin{array}{l}\text { TGW } \\
(\mathrm{g})\end{array}$ & $\begin{array}{l}\text { EP } \\
\text { (un.) }\end{array}$ & $\begin{array}{l}\text { Yield } \\
\left(\mathrm{kg} \mathrm{ha}^{-1}\right)\end{array}$ & $\begin{array}{l}\text { LI } \\
(\%)\end{array}$ \\
\hline Treat & 3 & $0.37 \mathrm{~ns}$ & $0.01 \mathrm{~ns}$ & $9.95 \mathrm{~ns}$ & $132.47 \mathrm{~ns}$ & $0.001 \mathrm{~ns}$ & $0.001 \mathrm{~ns}$ & $1082079 \mathrm{~ns}$ & $0.26 \mathrm{~ns}$ \\
\hline Block & 3 & $0.01 \mathrm{~ns}$ & $0.00 \mathrm{~ns}$ & $11.09 \mathrm{~ns}$ & $2798.31 \mathrm{~ns}$ & $0.001 \mathrm{~ns}$ & $0.001 \mathrm{~ns}$ & $1342779 \mathrm{~ns}$ & $0.15 \mathrm{~ns}$ \\
\hline Error & 9 & 0.44 & 0.01 & 26.90 & 1731.49 & 0.000 & 0.03 & 1640941 & 0.13 \\
\hline Main & & 12.47 & 1.97 & 44.80 & 355.29 & 413.00 & 0.71 & 7495.83 & 1.99 \\
\hline$\overline{\mathrm{CV} \%}$ & & 5.32 & 4.07 & 11.57 & 11.71 & 3.75 & 25.81 & 17.09 & 18.19 \\
\hline
\end{tabular}

*statistically different by the F-test at $\mathrm{p}<0.05$; ns, does not differ statistically by the F-test ( $\mathrm{p}>0.05)$; $\mathrm{SV}=$ sources of variation; $\mathrm{DF}=$ degrees of freedom; $\mathrm{CV}=$ coefficient of variation; a.u. = arbitrary unit.

Different independent studies reported an increase in the number of ears per maize plant when increasing rates of nitrogen were applied (FERREIRA et al. 2001, DUETE 2000, VELOSO 2006). The latter author also reported that prolificacy grows, but the second ear often becomes deformed, is very small and has few grains, implying that this increased prolificacy is ineffective to increase grain yield.

Although there was no reduction in the maize plant height when trinexapac-ethyl apliccations and nitrogen rates were used, there was no severe lodging in the plants because the weather did not favor its occurrence, particularly because maximum wind speed was low, on the order of $8.9 \mathrm{~km} \mathrm{~h}^{-1}$ (INMET 2014).

The use of plant growth regulators in order to minimize the occurrence of lodging and stem breakage is still restricted to research studies; even so, such possibility is promising for use in commercial crops. In a previous study, maize cultivars Z 958 and Pioneer 335, treated with a mixture of etefon and diethyl aminoethyl hexanoate, called EDAH, resulted in reduced lodging of the plants and a grain yield increase on the order of $8 \%$, but without changes in the quality of these grains (protein, fat and starch) (ZHANG et al. 2014). In Brazil, a study with trinexapac-ethyl in commercial maize hybrids Status TL and Maximus TLTG, reported no changes in morphological or productive parameters of this crop (ZAGONEL \& FERREIRA 2013).

In general, the experimental results reported in the present paper suggest the need for further research in order to gather evidence of higher yields and greater plant height in years with stable weather and, thus, assess the effectiveness of trinexapac-ethyl in reducing excessive vegetative vigor of maize plants promoted by the use of nitrogen sidedressing above the ideal level. Consequently, it can be determined how safely trinexapac-ethyl minimizes the occurrence of lodging in maize plants.

In conclusion, lodging, plant height, leaf chlorophyll, grain yield, thousand grain weight, protein and nitrogen levels in the maize grains were not affected by supraoptimal nitrogen application associated with the use of trinexapac-ethyl. There was only a slight decrease in leaves length with consequent increase in the width of maize plant leaves.

\section{ACKNOWLEDGEMENTS}

To CAPES (Coordination for the Improvement of Higher Education Personnel) for granting a Master's scholarship to the first author. To FAPESC-PAP (Research Support Program of the Santa Catarina State Research Foundation) for its aid with research and publication.

\section{REFERENCES}

BERGAMASCHI H et al. 2004. Distribuição hídrica no período crítico do milho e produção de grãos. Pesq. Agropecu. Bras. 39: 831-839.

CAMPOS FP et al. 2004. Métodos de análise de alimentos. Piracicaba: FEALQ 135p.

CIAMPITTI IA \& VYN TJ. 2014. Nutrient sufficiency concepts for modern corn hybrids: impacts of management practices and yield levels. Crops \& Soils Magazine. 47: 3844.

COMISSÃO DE QUÍMICA E FERTILIDADE DO SOLO - 
CQFS RS/SC. 2004. Manual de adubação e de calagem para os Estados do Rio Grande do Sul e de Santa Catarina.10. ed. Porto Alegre: Sociedade Brasileira de Ciência do Solo - Núcleo Regional Sul. 401p.

DUETE RRC. 2000. Estudo de doses, parcelamento e formas de nitrogênio na adubação de milho usando $15 \mathrm{~N}$. Tese (Doutorado em Energia Nuclear na Agricultura). São Paulo: UNESP. 152p.

FERNANDES FCS et al. 2005. Doses, eficiência e uso de nitrogênio por seis cultivares de milho. Revista Brasileira de Milho e Sorgo. 4: 195-204.

FERREIRAACB et al. 2001. Características agronômicas e nutricionais do milho adubado com nitrogênio, mobilidênio e zinco. Sci. Agríc. 58: 131-138.

INMET. 2014. Mapas de condições registradas: estações e dados - estações convencionais - Lages/SC. Disponível em: <http://www.inmet.gov.br/portal/index.php?r=home/ page\&page $=$ rede_estacoes_conv_graf $>$ acesso em: 09 set 2015.

LOURENTE ERP et al. 2007. Culturas antecessoras, doses e fontes de nitrogênio nos componentes de produção do milho. Acta Sci., Agron. 29: 55-61.

MEIRA FA et al. 2009. Fontes e épocas de aplicação do nitrogênio na cultura do milho irrigado. Semina: Ciências Agrárias. 30: 275-284.

MOES J \& STOBBE EH. 1991. Barley treated with ethephon: I. yield components and net grain yield. Agron. J. 83: 86-90.

MOTA MR et al. 2015. Fontes estabilizadas de nitrogênio como alternativa para aumentar o rendimento de grãos e a eficiência de uso do nitrogênio pelo milho. Rev. Bras. Cienc. Solo. 39: 512-522.

RADEMACHER W. 2000. Growth retardants: effects on gibberellin biosynthesis and other metabolic pathways. Annu. Rev. Plant Physiol. Plant Mol. Biol. 51: 501-531.

RITCHIE SW et al. 1993. How a corn plant develops. Ames: Iowa State University of Science and Technology (Special Report, 48). 26p.

SANGOI L et al. 2011. Perfilhamento, área foliar e produtividade do milho sob diferentes arranjos espaciais. Pesq. Agropecu. Bras. 46: 609-616.

SCHMITT A. 2012. Incremento na Densidade de plantas como estratégia para aumentar o rendimento de grãos de milho. In: 29 Congresso Nacional de Milho e Sorgo. Anais... Águas de Lindóia: ABMS, 2012. p.2009-2015.

SILVA EC da et al. 2006. Manejo de nitrogênio no milho sob plantio direto com diferentes plantas de cobertura, em Latossolo Vermelho. Pesq. Agropecu. Bras. 41: 477-486.

SOUZA LV de et al. 2008. Genetic control of grain yield and nitrogen use efficiency in tropical maize. Pesq. Agropecu. Bras. 43: 1517-1523.

VELOSO MEC et al. 2006. Doses de nitrogênio na cultura do milho, em solos de várzea, sob sistema de drenagem subterrânea. Revista Brasileira de Milho e Sorgo. 5: 382394.
ZAGONEL J \& FERREIRA C. 2013. Doses e épocas de aplicação de regulador de crescimento em híbridos de milho. Planta Daninha. 31: 395-402.

ZHANG Q et al. 2014. Maize yield and quality in response to plant density and application of a novel plant growth regulator. Field Crops Res. 164: 82-89. 